\title{
neofilolog
}

Czasopismo Polskiego Towarzystwa Neofilologicznego

ISSN 1429-2173, elSSN 2545-3971, 2021, NR 57/1, 79-100

http://dx.doi.org/10.14746/n.2021.57.1.6

http://poltowneo.org/

Mirosław Pawlak

Uniwersytet im. Adama M ickiewicza w Kaliszu Państwowa Wyższa Szkoła Zawodowa w Koninie https://orcid.org/0000-0001-7448-355X

pawlakmi@amu.edu.pl

\section{Nauczanie gramatyki języka obcego a podejście zadaniowe}

\section{Teaching grammar in a foreign language and task-based instruction}

While there is a consensus that teaching grammar is now indispensable in most educational contexts, there still exist numerous controversies as to how this should most beneficially be done. They concern, among others, such issues as the choice of instructional options to be used in order to introduce and practice grammar structures or to provide corrective feedback on errors made in the use of such structures (cf. Loewen, 2020; Nassaji, 2017; Pawlak, 2014, 2020a). On a more general level, a question arises as to the optimal way of organizing the material to be taught, with consequences for the overall approach to grammar instruction. One influential alternative to a structural syllabus, in which case grammar structures are carefully preselected and sequenced, is task-based language teaching, which can be conceptualized and implemented in various ways (cf. Ellis, 2017, 2018). The paper discusses the role of grammar in the taskbased approach, also taking into account techniques and procedures that can be employed for this purpose. An overview of existing empirical evidence will be presented and an attempt will be made to highlight the way in which communicative tasks can be used to assist grammar teaching in the Polish educational context.

Keywords: grammar instruction; task-based language teaching; tasksupported language teaching; communicative tasks

Słowa kluczowe: nauczanie gramatyki; podejście zadaniowe; podejście wspierane zadaniami; zadania komunikacyjne 


\section{Wprowadzenie}

Rola gramatyki w procesie uczenia się i nauczania języka obcego od wielu lat nie przestaje budzić licznych kontrowersji (Larsen-Freeman, 2010, 2014; Nassaji, Fotos, 2011; Pawlak, 2013b, 2014, 2020a). Jedną z najważniejszych jest niewątpliwie pytanie, czy ten podsystem powinien w ogóle być nauczany. Na przykład Krashen (1981) i zwolennicy jego teorii stoją na stanowisku, że o ile gramatyka w ogóle ma być nauczana, to powinno się to odbywać jedynie w minimalnym zakresie (Ellis, 2016; Nassaji, 2017; Pawlak, 2017, 2020a, 2021a). Prawda jest jednak taka, że w wielu kontekstach nauczanie gramatyki nigdy nie zostało zarzucone i choć oficjalnie zaakceptowano w nich kluczowe zasady podejścia komunikacyjnego (Littlewood, 2011), to ich implementacja nastręcza sporych problemów. Nie wynika to zresztą zazwyczaj z braku chęci czy złych intencji, ale po prostu z faktu, że ograniczony kontakt z tym czy innym językiem docelowym wymusza niejako nacisk na różne elementy systemu językowego, tak aby uczący się w ogóle mogli się nim posługiwać (por. Pawlak, 2021a).

Trzeba zresztą wyraźnie zaznaczyć, że ciągłe przywiązanie do wprowadzania i ćwiczenia struktur gramatycznych nie jest jedynie wynikiem specyfiki danego kontekstu edukacyjnego, lecz stanowi także odzwierciedlenie panującego wśród specjalistów przekonania, że nauczanie tego podsystemu jest po prostu niezbędne (Loewen, 2020; Nassaji, 2017; Nassaji, Fotos, 2011; Pawlak, 2014, 2020a, 2021a, 2021b, 2021c). Po pierwsze, nie wdając się w tym miejscu w zbędne szczegóły, pozytywny wpływ nauczania form języka, a w tym oczywiście gramatyki, jest podkreślany w wielu propozycjach teoretycznych podejmujących próbę wyjaśniania procesu nauki języka obcego, takich jak na przykład hipoteza interakcyjna (Long, 1996), hipoteza produkcji językowej (Swain, 1995), teoria uczenia się sprawności (DeKeyser, 1998), teoria przetwarzania danych językowych (VanPatten, 2015), czy nawet teoria dynamicznych systemów złożonych (Larsen-Freeman, 2015). Po drugie, wyniki badań empirycznych wyraźnie pokazują, że nauczanie gramatyki jest skuteczne w przypadku różnych struktur, gdyż pomaga ono nie tylko w lepszym opanowaniu reguł, lecz także w bardziej poprawnym ich stosowaniu w komunikacji. Dowodzą one również, iż pozytywne efekty takiej interwencji są w miarę trwałe (Ellis, 2008, 2016; Hinkel, 2017; Loewen, 2020; Nassaji, 2017; Nassaji, Fotos, 2011; Pawlak, 2014, 2020a, 2021c).

Pomimo tych wszystkich faktów, jest rzeczą oczywistą, że skuteczności nauczania gramatyki nie można w żadnym razie przyjmować za pewnik, gdyż uzależniona jest ona od szeregu decyzji związanych z organizacją tego procesu. Nie powinno zatem nadmiernie dziwić, że wciąż istnieją spore kontrowersje co do takich kwestii jak dobór nauczanych struktur, stosowane techniki 
nauczania, intensywność interwencji, najlepszy moment na rozpoczęcie nauki gramatyki, czy też wybór programu nau czania i sposób organizacji lekcji czy zajęć (zob. Ellis, 2006, 2016; Pawlak, 2017). To właśnie temu ostatniemu zagadnieniu poświęcony jest niniejszy artykuł, który ma celu rozważenie miejsca, jakie zajmuje nauczanie gramatyki języka obcego w podejściu zadaniowym oraz wskazanie, jak to podejście może zostać zastosowane w praktyce w polskim kontekście edukacyjnym. W pierwszej części tekstu zostaną pokrótce omówione zagadnienia dotyczące znajomości gramatyki oraz sposobów nauczania tego ważnego podsystemu. Następnie przedstawione będą kluczowe zasady podejścia zadaniowego, ze szczególnym naciskiem na samo pojęcie zadania komunikacyjnego, a także wyniki badań empirycznych w tym zakresie. Na zakończenie podjęta zostanie próba powiązania zasad podejścia zadaniowego z polską rzeczywistością edukacyjną przez wskazanie roli, jaką może odgrywać w nim nauczanie struktur gramatycznych. Zaprezentowana zostanie również autorska propozycja nauczania gramatyki wspomaganego zadaniami komunikacyjnymi.

\section{Znajomość gramatyki}

Kiedy postawimy pytanie, czym jest gramatyka i na czym polega jej znajomość, zdecydowana większość respondentów zapewne wspomni o różnego rodzaju regułach oraz ich opanowaniu na tyle, aby mogły one być poprawnie używane (Jean, Simard, 2011; Larsen-Freeman, 2014; Pawlak, 2020a). Co ciekawe, a jednocześnie bardzo niepokojące, wyniki prowadzonych badań pokazują, że podobnych odpowiedzi można się spodziewać od studentów filologii, również tych na specjalizacji nauczycielskiej, którzy uczęszczają na zajęcia z metodyki nauczania języków obcych, a w związku z tym powinni być świadomi, czym jest język obcy, jak przebiega proces uczenia się tego języka i w jaki sposób jest on używany w różnych sytuacjach. Podobne poglądy są również wyrażane przez doświadczonych nauczycieli języka obcego, którzy są przywiązani do tradycyjnych sposobów nauczania gramatyki, opartych w dużej mierze na wprowadzeniu i ćwiczeniu struktur gramatycznych (Jean, Simard, 2011; Pawlak, 2011, 2013a, 2020a). Choć trudno zaprzeczyć, że gramatyka opiera się w jakimś zakresie na regułach oraz ich poprawnym użyciu, utożsamianie jej tylko i wyłącznie z tymi regułami, poprawnością, czy też wiarą w to, że istnieje jedna poprawna odpowiedź to jeden z mitów, o których pisze Larsen-Freeman (2003).

Larsen-Freeman (2003) podkreśla, że gramatykę powinniśmy postrzegać nie tylko jako produkt, ale też jako proces, czyli jako narzędzie, które daje możliwość wyrażania zamierzonych przez użytkownika języka znaczeń w określonym kontekście. Innymi słowy, choć planowany przez nas komunikat można przekazać na wiele sposobów, przy wykorzystaniu różnych struktur gramatycznych, to 
my dokonujemy wyboru jednej z nich. Powoduje to, że nasz przekaz ma takie, a nie inne zabarwienie (np. pytanie można wyrazić za pomocą bardzo różnych form języka, sygnalizując w ten sposób różny poziom naszej wiedzy, oczekiwań itp.). Larsen-Freeman (2003) twierdzi także, że znajomość gramatyki jest wielowymiarowa i w przypadku każdej przyswajanej struktury obejmuje ona trzy odrębne, ale ściśle ze sobą powiązane elementy, tj.:

- aspekt strukturalny, który dotyczy sposobu, w jaki dana forma jest konstruowana,

- aspekt semantyczny, który odnosi się do znaczenia, jakie niesie ze sobą wykorzystanie tej czy innej struktury,

- aspekt pragmatyczny, który dotyczy celu, jaki chcemy osiągnąć wybierając określoną formę języka.

I tak na przykład stronę bierną w języku angielskim tworzy się przy użyciu czasowników to be lub to get, wybierając odpowiedni czas i aspekt, oraz imiesłowu czasu przeszłego. Zastosowanie jej oznacza, że bardziej interesuje nas wykonana czynność aniżeli osoba ją wykonująca, jest ona używana między innymi w przypadku, kiedy nie wiemy, kto odpowiada za dane wydarzenie albo chcemy nadać dyskursowi ton jak największego obiektywizmu (np. w pracach naukowych). Jak podkreśla Larsen-Freeman (2003), rolą nauczyciela jest określenie, który z tych trzech elementów stanowi źródło największych problemów dla uczących się i skupienie uwagi przede wszystkim na nim. Innymi słowy, sporym błędem jest próba koncentrowania się od razu na wszystkich trzech elementach, czy też na wszystkich możliwościach dotyczących każdego znich (np. formy strony biernej we wszystkich czasach gramatycznych), o czym będzie mowa poniżej.

Kolejną, chyba nawet o wiele ważniejszą, kwestią jest zasługujące na szczególną uwagę rozróżnienie między wiedzq eksplicytnq a wiedzq implicytnq czy też wysoce zautomatyzowanq (DeKeyser, 2010, 2017; Ellis, 2009; Pawlak, 2019). Ta pierwsza jest uświadomiona, ma charakter deklaratywny, nie podlega w zasadzie ograniczeniom związanym z wiekiem (oczywiście nie chodzi tutaj o naturalne procesy starzenia się) bądź naturalnymi procesami przyswajania języka (np. etapy rozwojowe, jakie trzeba przejść, aby móc używać pytań czy przeczeń) i może zostać zwerbalizowana, przy czym nie wymaga to zastosowania wyspecjalizowanej terminologii. Taka wiedza jest jednak w wielu przypadkach mało precyzyjna czy wręcz błędna, a co ważniejsze, dostęp do niej jest możliwy, kiedy uczący się ma na to odpowiednio dużo czasu. Jeśli chodzi o wiedzę implicytną, to jest ona nieuświadomiona, ma charakter proceduralny, a jej przyswojenie może być ograniczone wiekiem uczącego się (nauka języka po przekroczeniu tzw. wieku krytycznego, por. DeKeyser, Juffs, 2005), 
jak również wspomnianymi już wyżej naturalnymi sekwencjami w przyswajaniu języka obcego. Uczący się nie są w stanie opisać takiej wiedzy, ale jest ona bardziej stabilna, a kluczowe jest to, że stanowi ona podstawę spontanicznej komunikacji, która rzadko umożliwia świadome odwoływanie się do poznanych reguł. Innymi słowy, wiedza eksplicytna może pozwolić uczącemu się na poprawne użycie danej struktury podczas wykonywania ćwiczeń czy rozwiązywania testów (np. wstawianie wyrazów w odpowiedniej formie), ale nie będzie przydatna podczas codziennej rozmowy czy wykonywania zadań komunikacyjnych, bo tutaj niezbędna będzie wiedza implicytna. Jak jednak podkreśla DeKeyser (2017), w przypadku osób dorosłych, które nie mają zbyt wielu możliwości używania języka docelowego, na przykład podczas nauki języka angielskiego czy hiszpańskiego w Polsce, trudno jest mówić o wiedzy implicytnej w jej czystej postaci. W takiej sytuacji, nawet bardzo zaawansowani uczący się raczej nigdy nie zapomną poznanych reguł, ale mogą je zautomatyzować w takim stopniu, że będą stanowiły podstawę spontanicznych interakcji. Warto w tym miejscu również nadmienić, że istnieją różne poglądy na temat relacji między wiedzą eksplicytną a implicytną. I tak Krashen (1985) stoi na stanowisku, że ta pierwsza nie przekłada się na tę drugą, Ellis (1997) uważa, że jest to możliwe pod pewnymi warunkami, podczas gdy DeKeyser (2017) twierdzi, że jest to realne, o ile uczący się będą mieli możliwość wykorzystania reguł w zadaniach komunikacyjnych, co pozwoli na ich automatyzację. Z perspektywy nauczyciela, który od lat uczy gramatyki i widzi tego efekty w wypowiedziach uczniów, tak napraw dę rację bytu ma jednak tylko opcja ostatnia.

\section{Nauczanie gramatyki}

Istnieje bardzo wiele technik i procedur nauczania gramatyki, co sprawia, że nie sposób ich tutaj nawet w wielkim skrócie zaprezentować i omówić (zob. np. Doughty, Williams, 1998; Ellis, 1997; Loewen, 2011; Pawlak, 2006, 2013b, 2014, 2021b, 2021c). Dlatego też dyskusja w niniejszej sekcji ogranicza się jedynie do kilku podstawowych wyborów, których może dokonać nauczyciel i które zaprezentowane zostały na rys. 1. 


\section{Program nauczania}

- strukturalny

- zadaniowy

\section{Organizacja lekcji}

- tradycyjna (PPP)

- zaplanowany nacisk na formę języka

- niezaplanowany nacisk na formę języka

\section{W prowadzanie gramatyki}

- dedukcja

- indukcja

\section{Praktyka językowa}

- produkcja a recepcja

- zadania komunikacyjne a ćwiczenia

\section{Korekta błędów językowych}

- produkcja a recepcja

- bezpośrednia a pośrednia

Rysunek 1: Sposoby nauczania gramatyki (opracowanie autora).

Na najbardziej ogólnym poziomie niezbędne jest podjęcie decyzji dotyczącej sposobu doboru oraz organizacji materiału językowego. Choć można to oczywiście robić na różne sposoby (zob. Robinson, 2003), kluczowe dla obecnych rozważań jest rozróżnienie między strukturalnym programem nauczania i podejściem zadaniowym. W pierwszym przypadku struktury gramatyczne są starannie dobrane i uporządkowane według różnych kryteriów (np. częstotliwość, przydatność, trudność), a następnie po kolei wprowadzane i ćwiczone. W podejściu zadaniowym natomiast, które jest głównym przedmiotem zainteresowania niniejszego tekstu i które zostanie szerzej omówione poniżej (stąd wyróżnienie na rys. 1), nauczanie gramatyki w zasadzie powinno się odbywać w reakcji na antycypowany lub zaistniały już problem (Ellis, 2017, 2018). Decyzja o wyborze programu nauczania determinuje poniekąd sposób, w jaki są zaplanowane lekcje poświęcone nauczaniu gramatyki. I tak, wybór programu strukturalnego jest w zasadzie równoznaczny z zastosowaniem dobrze znanej i często stosowanej sekwencji, w której jest podawana reguła, 
a następnie dana struktura gramatyczna jest ćwiczona, najpierw w kontrolowanych ćwiczeniach (np. wstawianie wyrazów w odpowiedniej formie), a potem przy pomocy aktywności, które pozwalają na bardziej swobodne jej użycie (ang. presentation - practice - production, PPP). Warto tu jednak nadmienić, że ten trzeci element często w ogóle się nie pojawia w praktyce szkolnej, a nawet jeśli, to zwykle trudno jest mówić o w miarę autentycznej, spontanicznej interakcji. Jeśli natomiast stosowane jest podejście zadaniowe, to nauczenie struktur gramatycznych jest integralną częścią zadań komunikacyjnych. Da się to osiągnąć przez zaplanowany bądź też niezaplanowany nacisk na formę języka (ang. planned or unplanned focus on form). W pierwszym przypadku zadania są konstruowane w taki sposób, aby ich wykonanie wymagało użycia konkretnej struktury, często kosztem innych. Natomiast w drugim uwaga uczących się jest ukierunkowywana na różne struktury albo przez korektę błędów popełnianych w ich użyciu, albo przez podawanie wyjaśnień, które pojawienie się takich błędów niejako uprzedzają.

Kiedy gramatyka jest nauczana systemowo, jak ma to miejsce w przypadku programu strukturalnego, nauczyciele mają do wyboru szeroki wachlarz technik i procedur. Przy wprowadzaniu danej struktury można bowiem się odwołać do dedukcji przez podanie od razu odpowiedniej reguły, lub indukcji, kiedy uczący się sami muszą ją odkryć. W obu przypadkach istnieje też wiele różnych możliwości, które dotyczą na przykład odwoływania się do języka ojczystego, stosowania terminologii gramatycznej czy doboru materiałów i modalności, przy pomocy których dana reguła jest prezentowana czy odkrywana przez uczących się. Jeśli chodzi o ćwiczenie wprowadzonych struktur, to wykorzystywane w tym celu aktywności mogą wymagać od uczniów ich produkcji bądź ograniczać się do recepcji przez zwracanie ich uwagi na związek między daną formą, jej znaczeniem i użyciem. To pierwsze rozwiązanie jest stosowane zdecydowanie częściej, przy czym nacisk może zostać położony na tradycyjne ćwiczenia (np. tłumaczenie zdań lub ich parafrazowanie) lub zadania komunikacyjne (np. odnajdywanie różnic między obrazkami), z istotnym zastrzeżeniem, że większość aktywności będzie się sytuowała pomiędzy tymi dwoma ekstremami. I w końcu, niezależnie od dominującego rodzaju praktyki językowej, integralnym elementem nauczania gramatyki jest korekta pojawiajqcych się błędów, która może przyjąć mniej lub bardziej bezpośredni charakter, co oznacza, że uczący się mogą być mniej lub bardziej świadomi, iż są poprawiani. Wybrany sposób korekty determinuje również to, czy ma zostać podjęta próba autokorekty (tj. produkcja) czy też nie (tj. recepcja). Warto tutaj podkreślić, że w zasadzie wszystkie te techniki mogą się pojawiać w różnych konstelacjach w podejściu zadaniowym, które jest bardziej szczegółowo omówione w kolejnej części artykułu. 


\section{Charakterystyka podejścia zadaniowego}

Przed omówieniem specyfiki podejścia zadaniowego, trzeba sobie odpowiedzieć na pytanie, jak tak napraw dę należy interpretować zadanie. Po pierwsze, zadanie można rozumieć zarówno jako plan, czyli materiały które stanowią punkt wyjścia do jego wykonania (np. charakterystyka studentów, którzy mogą otrzymać stypendium), jak i jako proces, czyli interakcje, które odbywają się na podstawie tych materiałów i mogą przyjąć różny charakter, nie zawsze taki, jak zaplanowano (Breen, 1989). Innymi słowy, założenie, że przygotowane zadanie ma umożliwić spontaniczną komunikację wcale nie oznacza, że taka komunikacja rzeczywiście nastąpi. Po drugie, zadanie komunikacyjne musi spełniać kilka kluczowych kryteriów, a mianowicie:

- główny nacisk powinien zostać położony na przekazywanie znaczeń, a nie na ćwiczenie danej formy języka;

- powinno zawierać jasno określony cel komunikacyjny, przy czym nie może nim być jedynie poprawne użycie języka docelowego;

- powinna w nim pojawiać się pewna luka informacyjna, tak aby niezbędne było przekazanie jakiejś informacji, wyrażenie opinii itp.;

- uczący się powinni korzystać z własnej wiedzy językowej czy też niejęzykowej w celu wykonania zadania (np. nie mówimy im wprost, aby używali tej czy innej struktury);

- $\quad$ powinien występować związek między wykonywanym zadaniem a sytuacjami, w których używamy języka poza klasą;

- $\quad$ ewaluacja zadania powinna się w pierwszej kolejności skupiać na osiągnięciu zamierzonego celu językowego, a nie na poprawności użycia form języka (Ellis, 2003, 2017, 2018; Skehan, 1998).

Po trzecie, choć na podstawie wymienionych kryteriów można odnieść wrażenie, że w zadaniach komunikacyjnych w ogóle nie ma miejsca na nauczanie gramatyki, to sytuacja wygląda nieco inaczej. Przede wszystkim zadanie można zaprojektować w taki sposób, że wykonanie go jest trudne bez użycia danej struktury (np. opis sceny w parku wymaga użycia konkretnego czasu gramatycznego i odpowiedniego zestawu przyimków), choć uczący się mogą stosować różnego rodzaju strategie uniku. Jak już wspomniano wyżej, możliwe jest też zwracanie uwagi na formy językowe przed rozpoczęciem wykonywania zadania, co może być zainicjowane zarówno przez nauczyciela, jak i uczących się, a także poprawianie błędów w użyciu tych form podczas trwających interakcji bądź po ich zakończeniu. Tak czy inaczej, trzeba sobie jasno powiedzieć, że zdecydowana większość aktywności stosowanych podczas lekcji języka obcego 
na różnych etapach edukacyjnych nie spełnia podanych kryteriów i dlatego trudno je uznać za zadania komunikacyjne (np. Pawlak, 2020a). Nie jest nim z całą pewnością odgrywanie ról, gdzie uczący się pamięciowo opanowują swoje sekwencje czy też tworzenie pojedynczych zdań na podstawie obrazków. Inną kwestią jest to, czy możliwe i w ogóle potrzebne jest „ukrywanie” przed uczącymi się faktu, że zadanie pozwala na zastosowanie określonej struktury w komunikacji.

Podejście zadaniowe rozwinęło się w ramach podejścia komunikacyjnego i można je uznać za jedną z jego interpretacji (Ellis, 2017). Początkowo zadania odgrywały w podejściu komunikacyjnym rolę pomocniczą jako narzędzia umożliwiające rozwijanie płynności, które stanowiły ważne uzupełnienie tradycyjnych ćwiczeń służących rozwijaniu poprawności językowej. Z biegiem czasu wyłoniły się jednak dwa warianty tego podejścia, które określa się czasem mianem „słabego" i "mocnego" (ang. weak vs. strong CLT; Howatt, 1984). W pierwszym przypadku mamy tak naprawdę do czynienia ze strukturalnym programem nauczania oraz wspomnianą wyżej sekwencją PPP, a zadania komunikacyjne mają umożliwić w miarę spontaniczną produkcję językową w ostatniej jej fazie. M ożna więc tutaj mówić o nauce języka obcego dla komunikacji. Natomiast w drugim przypadku to odpowiednio dobrane oraz uszeregowane zadania stanowią trzon programu nauczania, a formy językowe mają drugorzędne znaczenie, co sprawia, że ma tutaj miejsce nauka języka obcego przez komunikację (Ellis, 2018).

Oba te warianty znalazły także swoje odzwierciedlenie w kluczowym rozróżnieniu między podejściem wspieranym zadaniami a podejściem zadaniowym w czystej postaci. Jak pokazuje zestawienie zaprezentowane w tabeli 1, istnieją pomiędzy nimi fundamentalne różnice. W podejściu wspieranym zadaniami punktem odniesienia jest lista struktur gramatycznych, główny nacisk jest położony na ich poprawne użycie, a nauczanie jest ukierunkowane na formy języka, co powoduje, że wykorzystywane są zarówno tradycyjne ćwiczenia, jak i zadania komunikacyjne. M amy więc do czynienia z transmisją wiedzy, uczenie się ma charakter intencjonalny, a podbudowę koncepcyjną stanowi teoria uczenia się sprawności (DeKeyser, 2017). Sytuacja wygląda inaczej w przypadku podejścia zadaniowego, gdyż punktem wyjścia są tu zadania komunikacyjne, punkt ciężkości jest położony na użycie języka dla komunikacji i to w tym kontekście nauczyciel może zwracać uwagę uczących się na formy językowe. Nie ma tutaj miejsca na tradycyjne ćwiczenia, uczenie się ma charakter incydentalny, a kluczową rolę odgrywa w nim doświadczenie. Uzasadnienie takiego sposobu nauczania można odnaleźć w szeroko pojętym podejściu interakcyjnym (Kim, 2017) oraz w podejściach akcentujących naukę języka przez kontakt z danymi językowymi (zob. Ellis, Wulff, 2015). 


\begin{tabular}{|l|l|l|}
\hline Kryterium & Podejście wspierane zadaniami & Podejście zadaniowe \\
\hline Program & Strukturalny & Zadaniowy \\
\hline Formy językowe & Ukierunkowanie na formę & Zwracanie uwagi na formę \\
\hline Aktywności & Ćwiczenia i zadania & Tylko zadania \\
\hline Główny nacisk & Poprawne użycie języka & Użycie języka dla komunikacji \\
\hline Uczenie się & Intencjonalne & Incydentalne \\
\hline Teoria uczenia się & Teoria złożonych sprawności & $\begin{array}{l}\text { Podejście interakcyjne } \\
\text { Podejścia akcentujące użycie języka }\end{array}$ \\
\hline Ogólne podejście & Transmisja wiedzy & Nauka przez doświadczenie \\
\hline
\end{tabular}

Tabela 1: Porównanie podejścia wspieranego zadaniami i podejścia zadaniowego (Ellis, 2017, 2018).

Prekursorami podejścia zadaniowego byli tacy specjaliści jak Long (1985), Breen (1989), Prabhu (1987) czy Nunan (1989), ale każdy z nich proponował nieco inną jego operacjonalizację. M imo że nadrzędnym celem tego podejścia jest stworzenie warunków, w których nauka języka następuje w naturalny sposób przez jego użycie w celu przekazywania znaczeń oraz osiągania autentycznych celów komunikacyjnych, tego typu różnice są też doskonale widoczne w bardziej aktualnych jego interpretacjach (np. Ellis, 2003; Long, 2015; Skehan, 1998; Willis, Willis, 2007). Podstawowe różnice dotyczą takich zagadnień jak sposób planowania kursu, rodzaje wykonywanych zadań, modalność, jaką te zadania angażują (tj. produkcja a recepcja), etap, na którym preferowane jest zwracanie uwagi uczących się na formę języka, ukierunkowanie na osobę uczącego się czy też odrzucenie bardziej tradycyjnych sposobów nauczania. I tak na przykład Long (2015), Skehan (1998) oraz Willis i Willis (2007) przyjmują za pewnik, że zadania muszą się opierać na produkcji językowej, a Ellis (2003) dopuszcza stosowanie takich, które ograniczają się do czytania i słuchania, szczególnie w przypadku mniej zaawansowanych uczących się. Jako jedyny uwzględnia on także stosowanie zadań komunikacyjnych wymagających użycia danej struktury (np. strony biernej), jak również odgrywanie przez nauczyciela bardziej dominującej roli w niektórych sytuacjach. Jeśli natomiast chodzi o zwracanie uwagi uczących się na formy języka, Long (2015) optuje, za ograniczeniem się do korekty błędów podczas wykonywania zadania, Skehan (1998) uważa, że powinno się to odbywać przed przystąpieniem do jego wykonania, Willis i Willis (2007) twierdzą, że najlepszym momentem 
jest faza po wykonaniu zadania, podczas gdy Ellis (2003) dopuszcza tego typu interwencję we wszystkich fazach jego realizacji.

\section{Badania empiryczne}

Choć istnieje sporo publikacji książkowych poświęconych temu, w jaki sposób należy implementować podejście zadaniowe (np. Ellis, 2003, 2018; Nunan, 2004; Skehan, 1998; Willis, 1996; Willis, Willis, 2007), niewiele jest badań, które w sposób holistyczny podejmowałyby próbę oceny jego efektywności, szczególnie w porównaniu z bardziej tradycyjnymi sposobami nauczania. Większość prowadzonych prac badawczych ogniskuje się na zadaniach komunikacyjnych, czy to w odniesieniu do sposobu, w jaki wspierają one proces nauki języka obcego, czy to pod kątem skuteczności różnych ich rodzajów oraz sposobów implementacji. Jeśli chodzi o pierwszą kwestię, istnieje wiele badań empirycznych, które pokazują, że wykorzystywanie zadań komunikacyjnych umożliwia negocjowanie form i znaczeń, co prowadzi do przyswojenia określonych form językowych (Mackay, Goo, 2007). Co więcej, odpowiednio prowadzona korekta błędów popełnianych w trakcie spontanicznych interakcji może się przyczynić do rozwoju nie tylko wiedzy eksplicytnej, ale również implicytnej, a jej efekty mają trwały charakter (por. Ellis, 2016; Nassaji, 2017; Pawlak, 2014). Wiele uwagi poświęca się też analizie różnych parametrów zadań, które mogą skutkować większą lub mniejszą ich efektywnością. Pierwszą ważną zmienną jest sposób, w jaki tego typu zadania sq skonstruowane, co dotyczy między innymi tego, czy wymagają one monologu czy dialogu, liczby elementów, które muszą zostać uwzględnione (np. opis całego mieszkania czy tylko jednego pokoju), rodzaju luki informacyjnej (np. dostęp do części obrazków, na podstawie których ma powstać narracja), stopnia znajomości tematyki zadania, rodzaju dyskursu (np. podawanie instrukcji to nie to samo, co argumentowanie) czy charakteru planowanego rozwiązania (np. istnieje określona liczba różnic między rysunkami, ale wyrażane opinie mogą być rozbieżne) (Ellis, 2003, 2017, 2018). Kolejną kluczową kwestią jest sposób, w jaki zadanie jest wykonywane. Chodzi tutaj o możliwość planowania przed i w trakcie jego wykonywania, jak również o to, czy jest ono powtarzane w takiej samej czy tylko nieco zmienionej formie. Ogólnie rzecz biorąc, czas na zaplanowanie interakcji czy sposobność wykonania danej aktywności po raz kolejny mają pozytywny, choć zazwyczaj odmienny wpływ na charakter wypowiedzi (Ellis, 2009). To właśnie jakość języka wykorzystywanego podczas wykonywania zadań jest ostatnim zagadnieniem, na którym koncentrują się badacze. O ile na początku punkt ciężkości był położony na występowanie negocjacji znaczeń (tj. rozwiązywanie pojawiających się problemów komunikacyjnych; np. Pawlak, 2004), to obecnie głównym przedmiotem 
zainteresowania są takie parametry wypowiedzi jak poprawność, płynność oraz stopień jej złożoności (np. Michel, 2017; Skehan, 2009).

Zapewne najbardziej interesujące, ale też najbardziej potrzebne $z$ dydaktycznego punktu widzenia są badania empiryczne, które porównywałyby skuteczność podejścia zadaniowego z podejściem jedynie wspieranym zadaniami, czy to w odniesieniu do całego programu nauczania czy też organizacji pewnej sekwencji zajęć. Takie badania prowadzone są jednak niezwykle rzadko, zapewne z uwagi na ogromne trudności związane z odpowiednim ich zaplanowaniem, implementacją interwencji dydaktycznej czy ewaluacją postępów (np. zapewnienie ciągłości i spójnego charakteru interwencji przez dłuższy czas, zniwelowanie wpływu pewnych zmiennych, choćby takich jak nauka we własnym zakresie). Problemy tego typu są zapewne przyczyną sprzecznych często rezultatów dotychczasowych projektów badawczych. Na przykład Pawlak (2012) podjął próbę oceny efektów nacisku na formę języka, czyli w jakimś sensie podejścia zadaniowego, oraz formy języka, czyli bardziej tradycyjnego podejścia, w przypadku trzeciego trybu warunkowego w języku angielskim podczas ośmiu lekcji w polskiej szkole średniej. Oba rodzaje interwencji miały podobny wpływ na rozwój wiedzy eksplicytnej i implicytnej. Broszkiewicz (2011) w badaniu, którego uczestnikami byli studenci filologii angielskiej, skupiła się na tej samej strukturze, porównując w szczególności efektywność zadań komunikacyjnych wymagających jej użycia i ćwiczeń, które pozwalały na jej zastosowanie w kontekście. Skuteczność obu podejść była podobna w przypadku wiedzy eksplicytnej, ale możliwość zastosowania struktury docelowej podczas w miarę spontanicznej komunikacji skutkowała większym rozwojem wiedzy implicytnej. Natomiast Shintani (2015) wykazała wyższość podejścia zadaniowego nad sekwencją PPP, szczególnie jeśli chodzi o incydentalną naukę słownictwa i struktur gramatycznych. Trzeba jednak pamiętać, że w tym badaniu udział wzięły dzieci uczące się języka angielskiego na poziomie początkującym, a zadania oparte były na recepcji i nie wymagały produkcji językowej. Wydaje się więc, że bardzo trudno byłoby wyciągać daleko idące wnioski na podstawie badań ogniskujących się na różnych grupach wiekowych i poziomach zaawansowania, odmiennych formach języka i różnych rodzajach interwencji dydaktycznej, zwłaszcza, że pomiar wiedzy językowej odbywał się w bardzo różny sposób.

\section{Podejście zadaniowe a dydaktyka}

Trzeba w tym miejscu wyraźnie stwierdzić, że jak do tej pory specjaliści nie przedstawili jednoznacznych wskazówek co do tego, w jaki sposób podejście zadaniowe miałoby znaleźć zastosowanie w praktyce, szczególnie w tych kontekstach edukacyjnych (takich jak polski), gdzie kontakt z językiem docelowym 
jest ograniczony. Istnieje bowiem zasadnicza różnica pomiędzy wykazaniem, że wykonywanie zadań komunikacyjnych przyczynia się do opanowania elementów języka docelowego, czy też, że pewne ich aspekty mogą odgrywać kluczową rolę $w$ tym zakresie a zaproponowaniem optymalnego sposobu organizacji zajęć wykorzystujących tego typu zadania, nie mówiąc już o organizacji całego kursu, który miałby się odwoływać do zasad podejścia zadaniowego. Jak trafnie zauważa Ellis (2017), istnieje więc ewidentna różnica między wynikami badań empirycznych a tym, co na co dzień dzieje się w klasie językowej. Nie oznacza to bynajmniej, że nie pojawiały się propozycje pewnych rozwiązań w tym zakresie. Na przykład Ellis (2003) proponuje, aby zadania koncentrujące się na recepcji poprzedzały te wymagające produkcji językowej. Baralt, Gilabert i Robinson (2014) przedstawiają bardzo konkretne rozwiązanie dotyczące tego, w jaki sposób zadania powinny zostać uszeregowane podczas kursu językowego, odnosząc się do czynników, które determinują stopień ich złożoności pod względem kognitywnym, co jest związane z naciskiem na formy języka i płynność wypowiedzi. I tak na przykład możliwość zaplanowania dyskursu oraz brak konieczności dokonywania logicznych wyborów sprawia, że dane zadanie staje się łatwiejsze, podczas gdy interakcja pod presją czasu, wymagająca dogłębnego przeanalizowania sytuacji w znacznym stopniu zwiększa poziom trudności.

Istnieją też propozycje rozwiązań dotyczących sposobu organizacji zajęć w podejściu zadaniowym oraz zaplanowania całego programu nauczania w oparciu o tę koncepcję. Specjaliści są zgodni w kwestii rozróżniania etapu poprzedzajqqcego wykonanie zadania, etapu jego wykonania oraz etapu, który następuje po jego zakończeniu (Lee, 2000; Skehan, 1996; Willis, 1996). Na tym jednak kończy się konsensus, ponieważ jedynie faza wykonywania zadania jest uważana za obligatoryjną i brak jest zgody co do tego, czy powinno się zwracać uwagę uczących się na formy języka na tym właśnie etapie, mimo że, jak wykazali Ellis i Shintani (2014), jest to w pełni uzasadnione. Pojawiają się znaczące kontrowersje co do tego, czy i w jaki sposób można implementować tzw. podejście modularne, które jest próbą integracji podejścia wspieranego zadaniami z podejściem zadaniowym w czystej postaci. Na przykład, podczas gdy Ellis (2018) stoi na stanowisku, że to drugie powinno być dominujące i odgrywać główną rolę na początkowych etapach nauki języka obcego, Pawlak (2006, 2013b) twierdzi, że bardziej uzasadniona w większości kontekstów edukacyjnych jest sytuacja, w której struktury gramatyczne są w pierwszej kolejności wprowadzane i ćwiczone, a dopiero potem pojawiają się możliw ości ich użycia w spontanicznej komunikacji. Takie możliwości muszą jednak zostać zapewnione, jeśli oczekujemy, że uczący się będą w stanie osiągać zamierzone cele komunikacyjne podczas spontanicznych interakcji, a przecież właśnie to jest istotą uczenia się i nauczania jakiegokolwiek języka obcego. 


\section{Rola nauczania gramatyki w podejściu zadaniowym}

Biorąc pod uwagę dotychczasowe rozważania, można z całą pewnością odnieść wrażenie, że podejście zadaniowe w swojej radykalnej wersji przypisuje dość marginalną rolę nauczaniu gramatyki. Jeśli bowiem przyjąć, że nacisk na formy języka powinien ograniczać się do trudności doświadczanych przez uczącego się w użyciu tej czy innej struktury, możliwości nauczycieli stają się bardzo ograniczone. Nie wchodzi bowiem w grę strukturalny program nauczania, w którym z góry ustalamy, jakie struktury będą wprowadzane i ćwiczone, choć dopuszczalną opcją jest stworzenie listy form języka, które powinny być w jakimś momencie w taki czy inny sposób wyeksponowane (Larsen-Freeman, 2003). Taka interwencja może się odbywać na bardzo różne sposoby, przy czym kluczowe znaczenie ma to, jaki jest jej charakter: zaplanowany czy niezaplanowany. Jeśli jest ona zaplanowana, to koncentrujemy się zwykle intensywnie na jednej formie, a jeśli nie, to zwracamy uwagę na wiele różnych struktur. Na przykład, zajęcia mogą być zorganizowane w taki sposób, że wykonywane jest zadanie, które wymaga użycia danej struktury, a negatywna informacja zwrotna (tj. korekta błędów) ogranicza się do przypadków, kiedy pojawiają się błędy w użyciu tej struktury. Alternatywą jest sytuacja, kiedy stosowane aktywności pozwalają na używanie szerokiej gamy struktur, z istotnym zastrzeżeniem, że w każdym momencie uczący się mogą poprosić o ich wyjaśnienie. Inicjatywa może być też po stronie nauczyciela i w każdym momencie może także nastąpić korekta błędów. W końcu nie można też wykluczyć integracji obu tych podejść, kiedy wykorzystywane są jednocześnie odpowiednio przygotowane zadania, podawane są wyjaśnienia i następuje korekta błędów.

W tym miejscu pojawia się jednak kluczowe pytanie o to, czy i w jakim zakresie podejście zadaniowe ma w ogóle rację bytu w sytuacji, kiedy uczący się mają ograniczone możliwości wykorzystania języka docelowego poza zajęciami, niezależnie od poziomu edukacyjnego, na jakim zajęcia te miałyby być prowadzone. Wydaje się bowiem, że możliwości aplikacji tego podejścia w jego czystej postaci są ograniczone, być może z wyjątkiem wyższych poziomów zawansowania, z którymi mamy do czynienia na filologicznych kierunkach studiów (filologia angielska, germańska, francuska itp.). W innych przypadkach nieodzowne jest jednak wprowadzanie i ćwiczenie niezbędnych reguł, czyli rozwijanie wiedzy eksplicytnej. Nie oznacza to jednak w żadnym wypadku, że nie powinno się stwarzać uczącym się licznych możliwości używania nauczanych struktur w komunikacji, gdyż tylko w ten sposób można mieć nadzieję na automatyzację tego rodzaju wiedzy, co gwarantuje jej wykorzystanie podczas w miarę spontanicznej komunikacji. 
Nauczanie gramatyki języka obcego a podejście zadaniowe

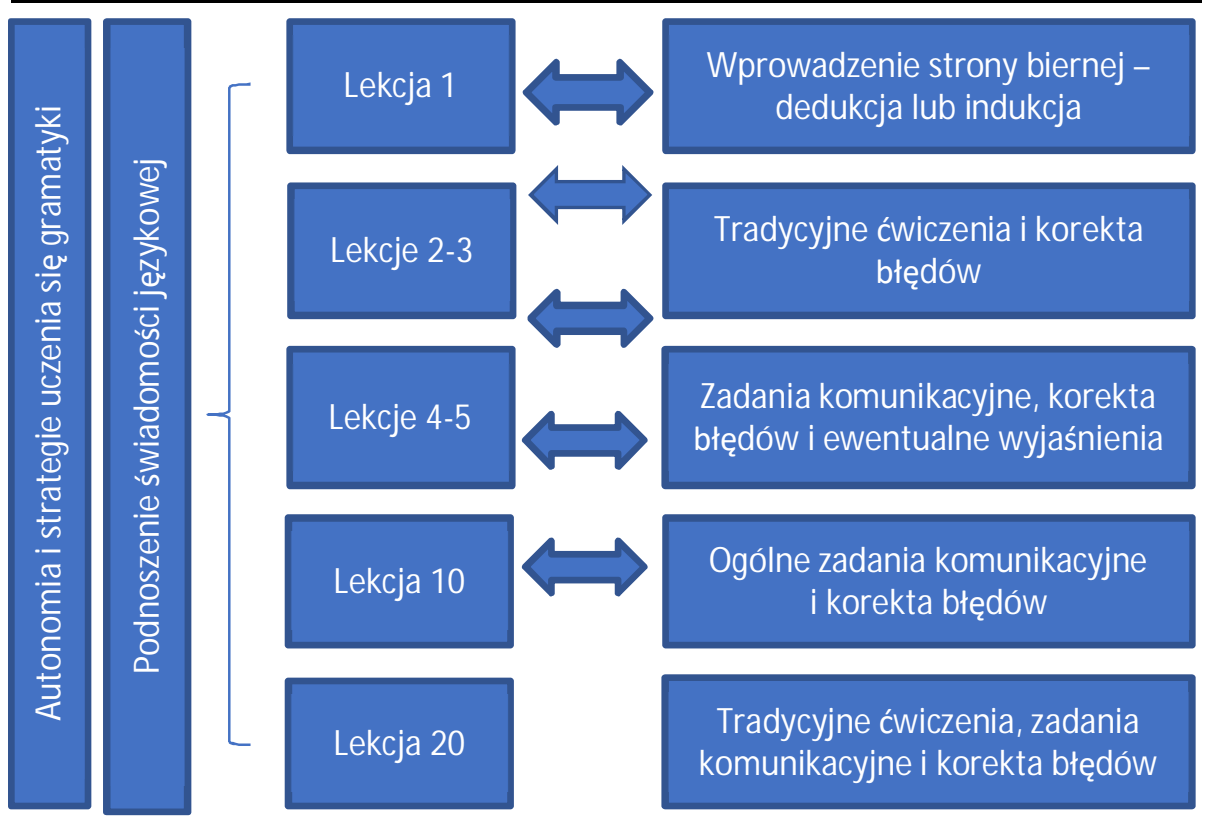

Rysunek 2: Propozycja włączenia zadań komunikacyjnych w nauczanie gramatyki (opracowanie autora).

Propozycja zastosowania zadań komunikacyjnych w nauczaniu gramatyki została zaprezentowana na rys. 2 na przykładzie strony biernej. Tak więc struktura ta jest najpierw wprowadzana, czy to przy użyciu dedukcji czy indukcji (Lekcja 1), z ważnym zastrzeżeniem, że koncentrujemy się jedynie na wybranych jej aspektach, takich jak jej użycie w czasie teraźniejszym i czasie przeszłym. Podczas kolejnych spotkań (Lekcje 2-3) strona bierna jest ćwiczona przy wykorzystaniu tradycyjnych ćwiczeń (np. tłumaczenie, parafrazowanie, tworzenie zdań), a popełniane błędy są konsekwentnie, w jasny sposób poprawiane i wyjaśniane. Podczas następnych kilku zajęć (Lekcje 4-5) wprowadzane są zadania komunikacyjne, w których niezbędne jest użycie strony biernej pod presją czasu. Korekta błędów jest ograniczona w dużej mierze do struktury docelowej, najczęściej pojawia się od razu, tak aby uczący się mógł dostrzec lukę w swojej wiedzy i może ona przyjąć bardzo różne, wspomniane wyżej formy (np. być bardziej lub mniej transparentna, wymagać autokorekty bądź też nie). W oczywisty sposób, z biegiem czasu, niezbędne będzie skoncentrowanie uwagi na innych strukturach, podsystemach i sprawnościach językowych, ale uczący się będą nadal próbowali używać strony biernej obok innych form językowych w zadaniach komunikacyjnych, które będą miały bardziej ogólny charakter i nie będą wymagały użycia konkretnej struktury (Lekcja 10). Tutaj 
również pojawiać się będzie korekta popełnianych błędów i, jeśli byłoby to konieczne, krótkie wyjaśnienia dotyczące tego, jak funkcjonuje strona bierna. W końcu nauczana struktura ponownie znajdzie się w centrum zainteresowania podczas lekcji powtórzeniowych (Lekcja 20), jednak nie muszą one polegać wyłącznie na wykonywaniu tradycyjnych ćwiczeń (np. wstawianie wyrazów w odpowiedniej formie, tłumaczenie zdań lub ich części), ale mogą również odwoływać się do różnych zadań o charakterze komunikacyjnym, wymagających produkcji i recepcji strony biernej.

Analizując zaprezentowaną sekwencję, warto zwrócić uwagę na kilka kluczowych kwestii. Po pierwsze, mamy tutaj do czynienia z podejściem modularnym, w którym strukturalny program nauczania oraz sekwencja PPP są z czasem w coraz to większym stopniu wspomagane zadaniami komunikacyjnymi. Trzeba również podkreślić, że kluczowe znaczenie ma spiralny układ materiału, w którym określona struktura, w tym przypadku strona bierna, pojawia się wielokrotnie w trakcie kursu, przy czym za każdym razem wprowadzane są kolejne, bardziej złożone jej elementy. Po drugie, nauczanie gramatyki jest postrzegane nie w odniesieniu do jednej lekcji, podczas której realizowana jest sekwencja PPP, ale raczej ich sekwencji, co pozwala na ćwiczenie danej struktury na różne sposoby. Po trzecie, proponowane rozwiązanie zakłada stosowanie zależnie od potrzeb różnych sposobów organizacji zajęć, przy czym nadrzędnym celem jest stworzenie licznych możliwości użycia strony biernej pod presją czasu, co pozwala na automatyzację wiedzy eksplicytnej. To z kolei implikuje duży nacisk na ostatni element procedury PPP, który jest obecnie często zaniedbywany. Po czwarte, możliwe jest wykorzystywanie całej palety technik oraz procedur służących wprowadzaniu i ćwiczeniu gramatyki, biorąc pod uwagę różnice indywidulane i specyfikę danego kontekstu edukacyjnego. Oznacza to również, że istnieje przestrzeń na nauczanie gramatyki nie tylko przez produkcję, ale również recepcję, co może być szczególnie ważne w przypadku grup, w których ten podsystem jest źródłem sporych problemów (np. niezależnie od programu nauczania, nie jest zasadne, aby nauczać produktywnego użycia mowy zależnej, jeśli uczący się nie potrafią poprawnie używać czasów gramatycznych). Po piąte, wbrew temu, co możemy często przeczytać w poradnikach dla nauczycieli (np. Harmer, 2015), zalecana jest korekta błędów w trakcie zadań komunikacyjnych, ponieważ pozwala ona na natychmiastowe dostrzeżenie problemu, sprzyjając rozwojowi wiedzy implicytnej lub automatyzacji wiedzy eksplicytnej. Po szóste, zalecana jest zmiana sposobu prowadzenia lekcji powtórzeniowych, które nie muszą się ograniczać w każdym przypadku do wykonywania kolejnej porcji nudnych ćwiczeń, ale mogą stanowić kolejną okazję do używania nauczanych struktur w komunikacji. Po siódme, jak przedstawiono na rys. 2, na wszystkich etapach 
nauczania gramatyki, w tym przypadku strony biernej, niezbędne jest rozwijanie autonomii uczących się w odniesieniu do uczenia się gramatyki (Pawlak, 2016). M ożna to między innymi osiągnąć przez odpowiednio prowadzony trening w zakresie strategii uczenia się gramatyki (Pawlak, 2020b), jak również podnoszenie świadomości językowej uczących się, na przykład w odniesieniu do różnic w funkcjonowaniu gramatyki w języku ojczystym i języku obcym. Po ósme w końcu, choć trudno było to uwzględnić w przedstawionym na rys. 2 modelu, niezbędna jest też zmiana w sposobie oceniania gramatyki, tak aby nie opierał się on tylko i wyłącznie na tradycyjnych testach, ale uwzględniał również użycie struktur gramatycznych w komunikacji (Pawlak, 2005, 2006).

W świetle powyższych rekomendacji nie sposób nie postawić pytania, czy te propozycje mają w ogóle rację bytu ze względu na ograniczoną ilość czasu, który nauczyciele mają do dyspozycji, aby zrealizować założenia podstawy programowej. Choć tego typu wątpliwości są w pełni uprawnione, warto się zastanowić nad dwoma kwestiami. Przede wszystkim, pojawia się fundamentalne pytanie, czy celem nauki języka obcego ma być tylko realizacja programu nauczania, co wymaga wprowadzenia wszystkich uwzględnionych w nim struktur, czy może jednak upewnienie się, że uczniowie będą w stanie używać z sukcesem przynajmniej niektórych z nich w trakcie spontanicznej komunikacji, która stanowi przecież esencję kształcenia językowego. Dla piszącego te słowa odpowiedź na to pytanie jest oczywista, bo chyba kształcenie językowe nie polega jedynie na tym, aby realizować zapisy podstawy programowej i innych dokumentów, ale w pierwszej kolejności na tym, aby uczący się potrafili wykorzystać wiedzę i umiejętności w codziennym życiu. Nie mniej ważne jest to, że zaprezentowany na rys. 2 model pozwala na osiągnięcie bardzo wielu celów, bo przecież uczący się mogą używać strony biernej przy rozwijaniu wielu innych sprawności i podsystemów. Na przykład zadanie komunikacyjne wymagające jej użycia może się wiązać z czytaniem, słuchaniem, mówieniem czy pisaniem, nie mówiąc już o tym, że można w tym czasie wprowadzać i ćwiczyć leksykę związaną z określoną tematyką.

\section{Zakończenie}

Jak wyraźnie wynika z powyższej dyskusji, podejście zadaniowe w czystej postaci nie jest kompatybilne z nauczaniem gramatyki, choć oczywiście uwzględnia ono możliwości zwracania uwagi uczących się na formy języka w różnych sytuacjach. Biorąc pod uwagę specyfikę polskiego kontekstu edukacyjnego możliw ości jego wykorzystania są w związku z tym ograniczone, być może z wyjątkiem sytuacji, kiedy mamy do czynienia z uczącymi się na wysokim poziomie zaawansowania, takimi jak studenci wyższych lat filologii czy też studenci innych 
kierunków bardzo dobrze posługujący się danym językiem obcym. Nie oznacza to jednak w żadnym wypadku, że na innych etapach edukacyjnych nie ma miejsca na stosowanie zadań komunikacyjnych, gdyż zawsze jest możliwa implementacja podejścia wspieranego zadaniami. Wręcz przeciwnie, jeśli chcemy, aby uczący się języka potrafili używać nauczanych struktur gramatycznych w komunikacji, częste wykorzystywanie różnego rodzaju zadań komunikacyjnych staje się po prostu nieodzowne. Innymi słowy, choć trudno mówić w polskim kontekście edukacyjnym o zupełnym zarzuceniu nauczania gramatyki, na pewno niezbędne jest zapewnienie równowagi między rozwijaniem wiedzy eksplicytnej w postaci znajomości reguł gramatycznych a jej automatyzacją, tak aby takie reguły można było wykorzystać w spontanicznej komunikacji.

\section{BIBLIOGRAFIA}

Baralt M ., Gilabert R., Robinson P. (2014), Task sequencing and instructed second language learning. London: Bloomsbury.

Breen M. (1989), The evaluation cycle for language learning tasks, (w:) Johnson R. K. (red.), The second language curriculum. Cambridge: Cambridge University Press, s. 187-206.

Broszkiewicz A. (2011), The effect of focused communication tasks on instructed acquisition of English past counterfactual conditionals. „Studies in Second Language Learning and Teaching", nr 1, s. 335-363.

DeKeyser R. (1998), Beyond focus on form: Cognitive perspectives on learning and practicing second language grammar. (w:) Williams J., Doughty C. (red.), Focus on form in second language acquisition. Cambridge: Cambridge University Press, s. 42-63.

DeKeyser R. (2010), Cognitive-psychological processes in second language learning, (w:) Long M. H., Doughty C. J. (red.), The handbook of language teaching. London: Wiley-Blackwell, s. 117-138.

DeKeyser R. (2017), Knowledge and skill in SLA, (w:) Loewen S., Sato M . (red.),

The Routledge handbook of instructed second language acquisition. New York: Routledge, s. 15-32.

DeKeyser R., Juffs A. (2005), Cognitive considerations in L2 learning, (w:) Hin-

kel E. (red.), Handbook of research in second language teaching and learning. Mahwah, NJ : Lawrence Erlbaum, s. 437-454.

Doughty C. J., Williams J. (1998). Pedagogical choices in focus on form, (w:)

Doughty C. J., Williams J. (red.), Focus on form in second language acquisition. Cambridge: Cambridge University Press, s. 197-261.

Ellis N. C., Wulff J. (2015), Usage-based approaches to SLA, (w:) VanPatten B., Williams J. (red.), Theories in second language acquisition. New York: Routledge, s. 75-93. 
Ellis R. (1997), SLA research and language teaching. Oxford: Oxford University Press. Ellis R. (2003), Task-based language learning and teaching. Oxford: Oxford University Press.

Ellis R. (2006), Current issues in the teaching of grammar: An SLA perspective. "TESOL Quarterly", nr 40, s. 83-107.

Ellis R. (2008). The study of second language acquisition (2nd ed.). Oxford: Oxford University Press.

Ellis R. (2009), The differential effects of three types of planning on fluency, complexity and accuracy in L2 oral production. „Applied Linguistics", nr 30, s. 474-509.

Ellis R. (2016), Focus on form: A critical review. „Language Teaching Research”, $\mathrm{nr} 20$, s. 405-428.

Ellis R. (2017), Task-based language teaching, (w:) Loewen S., Sato M. (red.), The Routledge handbook of instructed second language acquisition. New York: Routledge, s. 108-125.

Ellis R. (2018), Reflections on task-based language teaching. Oxford: Oxford University Press.

Ellis R., Shintani N. (2014). Exploring language pedagogy through second language acquisition research. London: Routledge.

Harmer J. (2015), The practice of English language teaching. Harlow: Pearson Longman.

Hinkel E. (2017), Prioritizing grammar to teach and not to teach: A research perspective, (w:) Hinkel E. (red.), The handbook of research in second language teaching and learning (vol. 3). New York: Routledge, s. 369-383.

Howatt A. P. R. (1984), A history of English language teaching. Oxford: Oxford University Press.

Jean G., Simard D. (2011), Grammar teaching and learning in L2: Necessary, but boring?. „Foreign Language Annals”, nr 44, s. 467-494.

Kim Y.-J. (2017), Cognitive-interactionist approaches to L2 instruction, (w:)

Loewen S., Sato M. (red.), The Routledge handbook of instructed second language acquisition. New York: Routledge, s. 126-145.

Krashen S. (1981), Second language acquisition and second language learning. London: Pergamon.

Krashen S. (1985), The input hypothesis: Issues and implications. New York: Longman.

Larsen-Freeman D. (2003), Teaching language: From grammar to grammaring. Boston: Thomson \& Heinle.

Larsen-Freeman D. (2010), Teaching and testing grammar, (w:) Long M. H., Doughty C. J. (red.), The handbook of language teaching. London: Blackwell, s. 518-542. 
Larsen-Freeman D. (2014), Research into practice: Grammar learning and teaching. "Language Teaching”, nr 48, s. 263-280.

Larsen-Freeman D. (2015), Complexity theory, (w:) VanPatten B., Williams J. (red.), Theories in second language acquisition: An introduction. New York: Routledge, s. 227-243.

Lee J. (2000), Tasks and communicating in language classrooms. Boston, M A: McGraw-Hill.

Littlewood W. (2011), Communicative language teaching: An expanding concept for a changing world, (w:) Hinkel E. (red.), The handbook of research in second language teaching and learning (vol. 2). New York: Routledge, s. 541-557.

Loewen S. (2011), Focus on form, (w:) Hinkel E. (red.), The handbook of research in second language teaching and learning (vol. 2). New York: Routledge, s. 576-592.

Loewen S. (2020), Introduction to instructed second language acquisition (2nd ed.). New York: Routledge.

Long M. H. (1985), A role for instruction in second language acquisition: Taskbased language teaching, (w:) Hyltenstam K., Pienemann M. (red.), Modeling and assessing second language acquisition. Clevedon: Multilingual Matters, s. 77-99.

Long M. H. (1996), The role of the linguistic environment in second language acquisition. (w:) Ritchie, W., Bhatia, T. (red.), Handbook of second language acquisition. San Diego: Academic Press, s. 413-468.

Long M. H. (2015), Second language acquisition and task-based language teaching. New York: Wiley.

M ackey A., Goo J. (2007), Interaction research in SLA: A meta-analysis and research synthesis, (w:) Mackey A. (red.), Conversational interaction in second language acquisition: A collection of empirical studies. Oxford: Oxford University Press, s. 407-453.

Michel M. (2017), Complexity, accuracy, and fluency in L2 production, (w:) Loewen S., Sato M. (red.), The Routledge handbook of instructed second language acquisition. New York: Routledge, s. 50-68.

Nassaji H. (2017), Grammar acquisition, (w:) Loewen S., Sato M. (red.), The Routledge handbook of instructed second language acquisition. New York: Routledge, s. 205-223.

Nassaji H., Fotos S. (2011), Teaching grammar in second language classrooms: Integrating form-focused instruction in communicative context. New York: Routledge.

Nunan D. (1989), Designing tasks for the communicative classroom. Cambridge: Cambridge University Press. 
Nunan D. (2004), Task-based language teaching. Cambridge: Cambridge University Press.

Pawlak M . (2004), Describing and researching interactive processes in the foreign language classroom. Konin: Wydawnictwo PWSZ w Koninie.

Pawlak M. (2005). Jak oceniać gramatykę. "Języki Obce w Szkole", nr 6, s. 34-41.

Pawlak M. (2006), The place of form-focused instruction in the foreign language classroom. Kalisz - Poznań: Adam M ickiewicz University Press.

Pawlak M. (2011), Cultural differences in perceptions of form/ focused instruction: The case of advanced Polish and Italian learners, (w:) Wojtaszek A., Arabski J. (red.), Aspects of culture in second language acquisition and foreign language learning. Heidelberg: Springer, s. 77-94.

Pawlak M . (2012), The effects of focus on forms and focus on form in teaching complex grammatical structures. „Indian Journal of Applied Linguistics”, nr 38, s. 35-56.

Pawlak M. (2013a), Comparing learners' and teachers' beliefs about form-focused instruction, (w:) Gabryś-Barker D., Piechurska-Kuciel E., Zybert J. (red.), Investigations in teaching and learning languages: Studies in honor of Hanna Komorowska. Heidelberg: Springer, s. 109-131.

Pawlak M . (2013b), Principles of instructed language learning revisited: Guidelines for effective grammar teaching in the foreign language classroom, (w:) Droździał-Szelest K., Pawlak M . (red.), Psycholinguistic and sociolinguistic perspectives on second language learning and teaching: Studies in honor of Waldemar Marton. Heidelberg: Springer, s. 199-220.

Pawlak M. (2014), Error correction in the foreign language classroom: Reconsidering the issues. Heidelberg: Springer.

Pawlak M . (2016), The role of autonomy in learning and teaching foreign language grammar, (w:) Pawlak M., Mystkowska-Wiertelak A., Bielak J. (red.), Autonomy in second language learning: $M$ anaging the resources. Heidelberg: Springer, s. 3-19.

Pawlak M. (2017), Individual differences variables as mediating influences on success and failure in form-focused instruction, (w:) Piechurska-Kuciel E., Szyszka M. (red.), At the crossroads: Challenges of foreign language learning. Heidelberg: Springer, s. 75-92.

Pawlak M. (2019), Tapping the distinction between explicit and implicit knowledge: Methodological issues, (w:) Lewandowska-Tomaszczyk B. (red.), Contacts \& contrasts in educational contexts and translation. Cham: Springer Nature, s. 45-60.

Pawlak M. (2020a), Grammar and good language teachers, (w:) Griffiths C., Tajeddin Z. (red.), Grammar and good language teachers. Cambridge: Cambridge University Press, s. 219-231. 
Pawlak M. (2020b), Grammar learning strategies as a key to mastering second language grammar: A research agenda. „Language Teaching”, nr 53, s. 358-370. Pawlak M. (2021a), Exploring the interface between individual difference variables and the knowledge of second language grammar. Cham: Springer Nature.

Pawlak M . (2021b), Teaching foreign language grammar to children: The role of individual differences. (w:) Rokita-Jaśkow J., Wolanin A. (red.), Facing diversity in child foreign language education. Cham: Springer, s. 56-71. Pawlak M . (2021c), Teaching foreign language grammar: New solutions, old problems. „Foreign Language Annals". https:// doi.org/10.1111/flan.12563

Prabhu N. S. (1987), Second language pedagogy. Oxford: Oxford University Press. Robinson P. (2003), Syllabus design, (w:) Long M. H. Doughty C. J. (red.), The handbook of language teaching. London: Blackwell, s. 294-310.

Shintani N. (2015), The incidental grammar acquisition in focus on form and focus on forms instruction for young, beginner learners. „TESOL Quarterly", nr 49, s. 115-140.

Skehan P. (1996), A framework for the implementation of task-based instruction. „Applied Linguistics”, nr 17, s. 38-62.

Skehan P. (1998). A cognitive approach to language learning. Oxford: Oxford University Press.

Skehan P. (2009), M odelling second language performance: Integrating complexity, accuracy, fluency, and lexis. „Applied Linguistics”, nr 30, s. 510-532.

Swain M. (1995), Three functions of output in second language learning, (w:) Cook G., Seidlhofer B. (red.), Principles and practice in the study of language: Studies in honor of H. G. Widdowson Oxford: Oxford University Press, 125-144.

VanPatten B. (2015), Input processing in adult SLA, (w:) VanPatten B. Williams J. (red.), Theories in second language acquisition: An introduction. New York: Routledge, s. 113-134.

Willis D., Willis). (2007), Doing task-based teaching. Oxford: Oxford University Press. Willis J. (1996), A framework for task-based learning. Harlow: Longman. 